Pamiętnik Literacki 2020, 3, s. 59-75

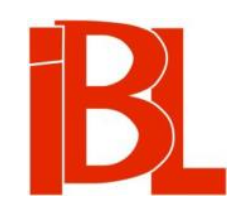

\title{
Sienkiewiczowski rok 1966 w kontekście peerelowskiej polityki historycznej
}

\author{
Aleksandra Chomiuk
}




\section{SIENKIEWICZOWSKI ROK 1966 W KONTEKŚCIE PEERELOWSKIEJ POLITYKI HISTORYCZNEJ}

Tadeusz Żeleński (Boy) stwierdził przed laty: „kariera pisarza nie kończy się z życiem: przeciwnie, ciagnnie się po śmierci, ma swoje niespodzianki, swoje złe i dobre szanse, swoje oportunizmy, ba, swoje protekcje [...]"'. Za specyficzną okazje pozwalającą objawić się pośmiertnej karierze twórcy można uznać uroczystości rocznicowe, które przez swoją masowość owe złe i dobre szanse jeszcze zwielokrotniają. Tematem rozważań uczynię jedną z takich rocznic, odwołując się do przykładu Henryka Sienkiewicza i obchodzonego w 1966 roku 50-lecia jego śmierci.

Wykorzystywanie postaci historycznych jako narzędzi legitymizowania współczesności jest zjawiskiem tak powszechnym, jak sama potrzeba tworzenia parenetycznych opowieści o dawnych bohaterach, a jubileusze oraz rocznice osobistości życia zbiorowego: artystów, naukowców, polityków, to jeden ze znaczących sposobów kształtowania pamięci kulturowej społeczeństw2 ${ }^{2}$. Na przestrzeni lat ewoluowała forma owych działań, pozostawała wszakże ich istota. Rocznicowe święto wykorzystuje bowiem autorytety i rytuały jako gwaranty statusu jego patrona. Możemy tu więc mówić o uwiarygodnianiu wielkości owych postaci w ramach przedsięwzięć naukowych oraz popularyzatorskich, o organizowanych akademiach czy wystawach muzealnych, wreszcie o medialnym wzmacnianiu rezonansu ich czynów lub wypowiedzi.

Obchody Sienkiewiczowskie pojawiły się w przestrzeni publicznej jeszcze za życia pisarza. W roku 1900 świętowano jubileusz jego pracy twórczej, a 16 lat później 70 rocznicę urodzin. W roku 1924 ważnym wydarzeniem stało się uroczyste sprowadzenie zwłok pisarza ze Szwajcarii do Warszawy. Na czasy PRL przypadły natomiast dwie okragłe rocznice: 100-lecie urodzin w roku 1946 oraz - 20 lat później - 50-lecie śmierci. Jeśli jednak w sytuacji tużpowojennej dominowały rozmaite oddolne inicjatywy regionalne: spotkania $\mathrm{w}$ miejscach związanych z pisarzem,

1 T. Boy-Żeleń s ki, Stulecie klasyka mimo woli. „Wiadomości Literackie” 1931, nr 7, s. 2.

2 Używam tu, za A. A s s m a n n (Przestrzenie pamięci. Formy i przemiany pamięci kulturowej. W zb.: Pamięć zbiorowa i kulturowa. Współczesna perspektywa niemiecka. Red. M. S a ry u s z - W ols ka. Kraków 2009 (przeł. P. Przybyła)), pojęcia pamięci kulturowej, nie zaś pamięci historycznej, ze względu na interesujący mnie związek tej pierwszej nie tyle $z$ samą przeszłością, ile $z$ rozmaitymi sposobami utrwalania wyobrażeń o niej w mediach, instytucjach i tekstach kultury. Jak pisze badaczka: „Zarówno jednostki, jak i kultury organizują swoją pamięć za pomocą zewnętrznych nośników i praktyk kulturowych” (ibidem, s. 112). 
prelekcje czy akademie ${ }^{3}$, to w roku $1966 \mathrm{w}$ sytuacji, gdy zatarł się ideologiczny pluralizm lat czterdziestych XX wieku, obchody straciły spontaniczność, zostały też, w znacznie większym stopniu niż poprzednie, scentralizowane i zinstytucjonalizowane.

W świetle prowadzonej w okresie gomułkowskim polityki historycznej ${ }^{4}$, która - wydawałoby się - nie przewidywała miejsca dla „piewców szlachetczyzny”, sensowne jest postawienie pytania o „pożytki” z Sienkiewicza w powojennej Polsce, szczególnie w kontekście wyraźnej dwuznaczności jego oficjalnego odbioru przez komunistów. Od początku swych rządów nowa władza wspierała się autorytetem pisarza wszędzie tam, gdzie mógł on pomóc w ukazaniu wyższości socjalistycznego sposobu życia nad kapitalistycznym ${ }^{5}$. W tym samym jednak czasie mielismy do czynienia $z$ niezwykle krytycznymi, by nie powiedzieć agresywnymi, wypowiedziami służącymi ideologicznej deprecjacji autora Trylogii. Były one rozwijane m.in. w ramach badań literaturoznawczych, dla których reprezentatywne pozostaje określenie twórcy jako „szlachecko-klerykalnego herolda zacofania”, przypisane mu przez Stefana Żołkiewskiego na wzór wcześniejszych inwektyw wyrażanych przez Stanisława Brzozowskiego czy Wacława Nałkowskiego ${ }^{6}$. Negatywny ton wybrzmiewał również $\mathrm{w}$ recenzjach cenzorskich dotyczacych publikowanych na przełomie lat czterdziestych i pięćdziesiątych XX wieku dzieł pisarza. Spośród dokumentów sporządzonych przez urzędników GUKPPiW (Głównego Urzędu Kontroli Prasy, Publikacji i Widowisk) uwage zwraca notatka sformułowana na marginesie powieści Wiry. Poza krytyką samego tego utworu, co raczej nie jest szczególnym zaskoczeniem ze względu na jego antyrewolucyjną i antyrosyjską wymowę, pojawia się tam bowiem uogólniona opinia kwestionująca celowość całościowej edycji spuścizny noblisty właśnie przygotowywanej przez Juliana Krzyżanowskiego:

Popularyzacja twórczości takich autorów, jak Dygasiński, Prus, Sienkiewicz, z których każdy na-

3 Zob. więcej na temat tych obchodów: A. C h o mi u k, Henryk Sienkiewicz w roku 1946. Dyskurs o pisarzu $w$ setna rocznice urodzin. W zb.: Henryk Sienkiewicz $w$ literaturze $i$ krytyce literackiej. Red. D. Samborska-Kukuć, T. Sobieraj. Warszawa 2018.

4 Za E. Ponczki em (Polityka wobec pamięci versus polityka historyczna. Aspekty semantyczny, aksjologiczny i merytoryczny $w$ narracji polskiej. „Przegląd Politologiczny” 2013, nr 2, s. 1) odczytuję politykę historyczna jako ,jeden ze sposobów "uprawiania polityki", w trakcie którego prawdziwą bądź mniej lub bardziej sfalsyfikowaną i zmityzowaną wiedzę o dziejach traktuje się instrumentalnie, a więc jako środek do utrzymania władzy lub jej zdobycia bądź partycypowania w niej”. Dodatkowo odwołuję się do memorystycznego wymiaru tego zjawiska, o którym można powiedzieć, że „funduje porządek pamięci, nadaje ramy temu, co może i powinno się pojawić, a także określa, w jaki sposób może się pojawić, pragmatyzuje opowieść o przeszłości. Ma wytworzyć lub wzmocnić wspólnotę, wyklucza lub potwierdza zbiorową przynależność” (K. Chmielewska, Ćwiczenia praktyczne z polityki historycznej. Narracje historyczne lat sześćdziesiatych $w$ Polsce. W zb.: Rok 1966. PRL na zakręcie. Red. K. Chmielewska, G. Wołowiec, T. Żu kows ki. Warszawa 2014, s. 197).

5 Zob. J. Szta ch els ka: Zabijanie klasyków. „Casus”: Sienkiewicz. „Przegląd Humanistyczny” 2011, nr 5; PRL-owski żywot Henryka Sienkiewicza. W zb.: Kariera pisarza w PRL-u. Red. M. B u dnik, K. Budrowska, E. Dąbrowicz, K. Kościewicz. Warszawa 2014; W meandrach PRL-owskiej krytyki. Sienkiewicz między Stawarem a Kijowskim. W zb.: Sienkiewicz polityczny. Sienkiewicz ideologiczny. Red. M. Glog e r, R. Ko zi ołek. Warszawa 2016.

6 S. Żółkiewski, wstęp w: W. Nałkowski, Pisma społeczne. Wybór, oprac. S. Żółkiewski. Warszawa 1951, s. 21. 
stawiony jest prokapitalistycznie, a ponadto w mniejszym lub większym stopniu antysocjalistycznie, wymaga szczególnego ustosunkowania się. Słuszna jest rzeczą dać społeczeństwu możność zapoznania się z twórczością tych naprawdę utalentowanych pisarzy, niemniej uprzystępniając ich społeczeństwu polskiemu w chwili obecnej i to świadomie w postaci wielkich piór i umysłów, nie możemy nie narażać się na ryzyko, że czytelnicy zużytkują ich argumenty antysocjalistyczne przeciwko dzisiejszemu ustrojowi i budownictwu socjalistycznemu w ogóle ${ }^{7}$.

Skoro jednak, mimo politycznych ataków, Dzieła twórcy (dodajmy, że łącznie z Wirami, choć równocześnie z pominięciem najbardziej drażliwego nurtu publicystyki politycznej) znalazły się na rynku księgarskim w najczarniejszym dla polskiej kultury okresie stalinizmu, a ponad dekadę później pamięć „reakcyjnego” pisarza uhonorowano ogólnopolskimi obchodami, to zasadne staje się pytanie o miejsce jego utworów - w tym przede wszystkim Trylogii jako dzieła najmocniej zanurzonego w obiegu polskiej kultury - w służbie nowych idei. Zanim odniosę się do tego problemu w kontekście roku 1966, przypomnę, że refleksja nad obecnością noblisty w peerelowskiej rzeczywistości polityczno-kulturowej pojawiła się jeszcze przed jubileuszem w ramach ankiety londyńskich „Wiadomości”. Jedno z pytań skierowanych do znanych osobistości życia emigracyjnego brzmiało w niej następująco: „Jak Pan(i) tłumaczy oficjalna aprobatę w Polsce kultu Sienkiewicza, pisarza dalekiego już nie tylko od komunizmu, ale i od wszelkiej lewicowości?" ${ }^{8}$. Wyjaśnienie możliwych powodów tolerowania przez peerelowskie władze twórczości Sienkiewicza (uważam, podobnie jak wypowiadający się w ankiecie Zbigniew Grabowski, iż zawarte w pytaniu określenie: „oficjalna aprobata”, jest w odniesieniu do politycznej recepcji pisarza w okresie gomułkowskim zdecydowanie na wyrost ${ }^{9}$ ) było dwojakie. Jedni respondenci (Michał Sambor, Marya Kasterska, Beata Obertyńska, Zygmunt Markiewicz, Stanisław Baliński) przyjmowali założenie, że autora tej miary, niezależnie od jego poglądów, nie sposób wypchnąć z przestrzeni publicznej bezkarnie. Ich zdaniem, także komuniści musieli więc uznać, iż lepiej go tam pozostawić, przy wykorzystaniu polityki edukacyjnej i wydawniczej do sterowania odbiorem twórczości. Natomiast druga część respondentów (Jan Roztworowski i Felicjan Sławoj Składkowski) formułowała tezę, że zgoda władz na Sienkiewicza wynika z czegoś zupełnie innego, mianowicie $z$ przeświadczenia o absolutnej nieprzystawalności jego historycznego pisarstwa do powojennych problemów. Zgodnie z tym założeniem:

Czytanie opisu walk i rozstrzyganie zagadnień społecznych sprzed stuleci daje nieszkodliwy upust fantazji i energii społeczeństwa. Cenzura obecna, podobnie jak dawna carska, uważa to za zręczne kanalizowanie nacjonalistycznych nastrojów i wyszumienie się psychiczne opornych, zadziornych elementów społecznych. Odległość w czasie, różnica w stosunkach społecznych i metodach walki wyłącza

AAN (Archiwum Akt Nowych), GUKPPiW, sygn. 386, z. 31/122, k. 777-778. Cyt. z: „Dzieła” Henryka Sienkiewicza $w$ dokumentach Głównego Urzędu Kontroli Prasy, Publikacji i Widowisk (19481954). Wybór, oprac. nauk., wstęp K. Bu d row s ka, K. Kościewi cz. Oprac. red. M. B ud nik, W. Gard o c ki. Białystok 2016, s. 96.

8 Nasz stosunek do twórczości Sienkiewicza. Ankieta „Wiadomości”. „Wiadomości” (Londyn) 1961, nry 5-7 (774-776), 9 (778), 11-12 (780-781). Za swoiste dopełnienie ankiety (przede wszystkim w jej nurcie apologetyczno-obronnym wobec noblisty) można uznać emigracyjną publikację rocznicową Sienkiewicz żywy (Red. W. G ü n th e r. Londyn 1967).

9 Z. Gra b o w s ki, głos w dyskusji Nasz stosunek do twórczości Sienkiewicza. Ankieta „Wiadomości”. Jw., nr 6 (775), s. 5. 
tu analogię z sytuacją obecna życia w Polsce. Nawet dobrze jest dla władz komunistycznych wskazać anomalie ówczesnych stosunków społecznych ${ }^{10}$.

Który więc z poglądów lepiej objaśnia motywy działania powojennej władzy? Wydaje się, że o lekceważeniu przez nią Sienkiewicza jako ideologa nie może być jednak mowy. Zdecydowanie chodzi natomiast o próby wykorzystania autorytetu i popularności twórcy do własnych celów, a także o minimalizowanie szkód ideologicznych związanych z przekazami nie dającymi się tym celom podporządkować. Należy tu przypomnieć już wcześniej docenione mimowolne „zasługi” noblisty dla polityki prowadzonej przez powojenne władze. Był on przecież wydawany masowo jako autor opowieści o trudnej doli ludu oraz „odkryty” jako demaskator stosunków społecznych w Stanach Zjednoczonych w spreparowanym dziele O Ameryce, którego nigdy przecież $\mathrm{w}$ takiej formie nie napisał ${ }^{11}$. Natomiast powieść Krzyżacy (następnie zaś jej wersja filmowa) stała się jednym z nośników powojennej germanofobii. Skoro też ekranizacja Aleksandra Forda z roku 1960 potwierdziła potencjał historycznej twórczości Sienkiewicza jako podstawy kolejnych scenariuszy dających nadzieję na przyciagnnięcie widzów do kin, a także dowiodła żywej popularności w społeczeństwie polskim dzieł opiewających przeszłość w tonie heroiczno-romansowym, mogło to stać się argumentem za poszerzeniem sfery pozytywnych nawiązań historycznych również o odpowiednio spreparowaną filmową Trylogię.

Niezależnie wszakże od tych szczegółowych powodów, dla których Sienkiewicz, mimo kontrowersji, które wzbudzał, bywał władzom przydatny, za istotny kontekst politycznej decyzji o uczczeniu na poziomie ogólnopolskim 50 rocznicy śmierci pisarza wypada też uznać ogólniejsze ideowe tło lat sześćdziesiątych. Jak podkreślają badacze dziejów najnowszych, była to dekada przełomowa w obliczu wyzwań politycznych stojaccych przed władza. Wtedy bowiem nastapiła kulminacja jednego z najważniejszych sporów w PRL, toczonego między Kościołem katolickim a władzą komunistyczną. Katalizatorem konfliktu stał się jubileusz Tysiąclecia Państwa Polskiego ${ }^{12}$, kiedy świeckim obchodom wielowiekowego rozwoju polskiej państwowości zwieńczonego powstaniem PRL przeciwstawiono uroczystości eksponujące rolę Kościoła katolickiego jako głównego gwaranta ciagłości narodowej i dziedzica tradycji historycznej. Stawką konfrontacji dwu rocznicowych porządków utrwalających konkurencyjne wizje 1000-letnich polskich dziejów, nie dające się pogodzić już na poziomie określających je nazw, było - jak pisza językiem Pierre’a Bourdieu autorzy wstępu do pracy Rok 1966. PRL na zakręcie - „prawo do prawomocnej

10 F. Sławoj Składkowski, głos w dyskusji: jw.

11 H. Sienkiewic z, O Ameryce. Opowiadania i wybór listów z podróży. Oprac., wstęp Z. W a s ilews ki. Warszawa 1953.

12 Tym mianem określały rocznicę peerelowskie władze, natomiast w dokumentach kościelnych była mowa o Milenium Chrztu Polski. Różnica dotyczy tu nie tylko terminologii, ale przede wszystkim ma wydźwięk ideologiczny (zob. T. Żu k ow s k i, Ustanowienie nacjonalistycznego pola dyskursu społecznego. Spór między partią a Kościołem w roku 1966. W zb.: Rok 1966. - P. S t a c h o w i a k, Główne watki narracji historycznej kościoła podczas obchodów milenijnych w 1966 r. Przyczynek do rekonstrukcji „kościelnej polityki pamięci”. W zb.: Pół wieku milenium. Religijne, polityczne i społeczne aspekty obchodów tysiąclecia chrztu Polski 〈1956-1966/1967〉. Studia i materiaty. Red. nauk. B. N o s z c zak. Warszawa 2017). 
reprezentacji [narodu] i [...] zasady legitymizacji w polu kulturowym, społecznym i politycznym"13.

Ta zintensyfikowana od końca lat pięćdziesiątych XX stulecia wojna o pamięć, która ukazała wielką siłę mobilizacyjną Kościoła i jego realne wpływy na Polaków, wymusiła na władzy poszukiwanie nowych płaszczyzn społecznego porozumienia. Jednym zaś z rezultatów ideowej korekty stało się łagodzenie retoryki rewolucyjnej na rzecz historycznych nawiązań o charakterze patriotycznym ${ }^{14}$. Skutkiem przesunięcia w latach sześćdziesiątych akcentów w ramach polityki historycznej państwa są choćby masowe wydania książek apologety polskiego czynu zbrojnego - Zbigniewa Załuskiego.

Czy wobec tego nałożenie obchodów półwiecza śmierci Sienkiewicza na rocznicę milenijną można odbierać jako podjętą wówczas przez komunistów kolejną próbę poszerzenia sfery pamięci kulturowej, w której znalazłoby się miejsce nie tylko dla piastowskich korzeni, dla Grunwaldu czy dla opisywanych przez autora Siedmiu polskich grzechów głównych XIX- i XX-wiecznych bitew, ale także dla tradycji Rzeczypospolitej Obojga Narodów? Szukając odpowiedzi na to pytanie, wypadałoby przede wszystkim podkreślić, że owo poszerzenie nie jest ani pełne, ani bezwarunkowe. Nawet bowiem samo środowisko partyjne nie było w tym względzie zgodne i konsekwentne. Przykład może stanowić choćby postawa Władysława Gomułki, którego retoryka w połowie lat sześćdziesiątych oscylowała między tradycyjną niechęcią do Polski szlacheckiej a potrzebą pragmatycznych ustępstw w sferze symbolicznych odniesień do tego okresu naszych dziejów. $Z$ jednej więc strony, mamy deklaratywne wzbogacanie narodowego dziedzictwa, odzwierciedlone choćby w sejmowym przemówieniu polityka z 21 VII 1966, w którym już nie tylko odwołał się on do „dorobku historycznego polskiego ludu pracującego”, ale (z wszystkimi zastrzeżeniami) podkreślił również wartość tego, „co w przeszłości dla Polski, dla jej rozwoju i dobra uczyniły inne klasy, stany i warstwy społeczne - monarchowie i szlachta, patrycjat miejski i duchowieństwo, ludzie nauki i kultury" ${ }^{15}$. $Z$ drugiej, w tym samym wystąpieniu znajdujemy u Gomułki kolejny raz potępienie „oligarchii magnackiej, sobiepaństwa możnych, obskurantyzmu i fanatyzmu triumfującej kontrreformacji, które w krótkim czasie roztrwoniły siły i dorobek wielu poprzednich pokoleń" ${ }^{16}$.

Diagnozę stopnia przyswojenia - w ramach oficjalnej polityki historycznej z połowy lat sześćdziesiątych - obrazu XVII wieku zawartego w Trylogii oprę na analizie storyka, który w tym samym czasie na łamach popularnego tygodnika pisał o „nieograniczonej wolności osobistej i stanowej szlachty, ksenofobii, samouwielbieniu, megalomanii narodowej połączonej z wiara w posłannictwo dziejowe, nietolerancji, dewocjonalizmie, orientalizacji obyczaju” (W. T o m ki e w i c z, W kręgu kultury sarmatyzmu. „Kultura” 1966, nr 39, s. 6).

Od redaktorów. Wstęp w zb.: Rok 1966, s. 5.

Zob. więcej na ten temat: M. Za r e m b a, Komunizm, legitymizacja, nacjonalizm. Nacjonalistyczna legitymizacja władzy komunistycznej w Polsce. Warszawa 2001, s. 263-352.

W. G o m ułk a, 1000 lat Polski. Przemówienie wygłoszone na uroczystej sesji Sejmu w dniu 21 VII 1966 r. Warszawa 1966, s. 5-6. Za podobnego typu gest należy uznać obecność husarii na zorganizowanej w Warszawie 22 VII 1966 „defiladzie tysiąclecia” (zob. A. D u dek, Milenium kontra Tysiaclecie. Na stronie: https://dzieje.pl/artykulyhistoryczne/prof-antoni-dudek-milenium-kontratysiaclecie 〈data dostępu: 1 III 2019)).

G o m ułka, op. cit., s. 23. Warto tu również przypomnieć wypowiedź wtórującego politykowi hihtto://rcin.org.p 
kilku rocznicowych debat, które wyznaczają pole ideowego konsensusu dotyczacego zarysowanej przez noblistę wizji przeszłości. Przyjrzę się wybranym dyskusjom związanym z sienkiewiczowskimi ekranizacjami, odniosę się do głosu o pisarzu wypowiedzianego podczas Kongresu Kultury Polskiej oraz wskażę główne założenia zorganizowanej przez Instytut Badań Literackich konferencji poświęconej Sienkiewiczowi. Dla możliwie szerokiego zarysowania zagadnienia ważne jest to, że owe wypowiedzi były kierowane do rozmaitych odbiorców, wygłaszane w odmiennych okolicznościach i podporządkowane zróżnicowanym celom. Pierwszą debatę można uznać za próbę wypracowania oficjalnego stanowiska dotyczącego sposobu przystosowania adaptacji Trylogii do oczekiwań masowego widza, przemówienie kongresowe to poszukiwanie punktów zbieżności między wpisaną w cykl historyczny aksjologia a wartościami akceptowanymi $\mathrm{w}$ ramach socjalistycznego państwa, wreszcie ostatni zbiór wystapień wzmacnia charakterystyczny dla lat powojennych nowy wymiar naukowej refleksji nad pisarzem $z$ dominującymi nurtami: recepcyjnym i warsztatowym. Wszystkie te głosy ujawniaja, do jakich schematów chciano w tym czasie przykroić twórczość Sienkiewicza i jakie perspektywy poznawcze z nią wiązano. To bowiem, co trzeba określić jako element wspólny w przedstawianej tu dyspucie, dotyczy próby istotnego przesunięcia recepcji jego powieści od matrycy historyczno-patriotycznej z postrzeganiem cyklu jako „biblii polskości” do odbioru uniwersalizującego przekaz i nadającego mu wymiar ludyczny.

Oczywiście, zasygnalizowane tu zmiany recepcyjne nie zaszły z dnia na dzień. Dwie kluczowe dla przedefiniowania sposobu odczytania Trylogii prace - Kazimierza Wyki i Zygmunta Szweykowskiego - pochodzą jeszcze $z$ lat czterdziestych ${ }^{17}$. Abstrahując też od dociekań literaturoznawców: czynnikiem istotnym dla przekształceń w zakresie stylów odbioru dzieła ${ }^{18}$ był sam upływ czasu i zmieniająca się polityczno-kulturowa świadomość kolejnych generacji czytelników. Czym innym było ono przecież dla Polaków ukształtowanych przez szkołę międzywojenna z jej nadrzędnym celem wychowania patriotyczno-narodowego ${ }^{19}$, a czym innym dla pokoleń edukowanych już po wojnie. Niewątpliwie eksponowanie w badanych publicystycznych i naukowych wypowiedziach walorów rozrywkowych cyklu współgra również ze zintensyfikowanym w latach sześćdziesiątych procesem ujednolicania kulturowych doświadczeń społeczeństwa i spłaszczania różnic między estetycznymi oczekiwaniami odbiorców przynależnych do różnych jego kręgów ${ }^{20}$. Patrząc $z$ tej perspektywy, można powiedzieć, iż wymienione tu okołorocznicowe przedsięwzięcia,

K. Wy ka, Sprawa Sienkiewicza. „Twórczość” 1946, nr 6. - Z. S z w e y k o w s ki, „Trylogia” Sienkiewicza jako baśń na tle dziejowym. „Życie Literackie” 1946, nr 12.

18 Pojęcie stylu odbioru odnoszę tu do ponadindywidualnych norm lektury, ukształtowanych społecznie, np. w ramach działań edukacyjnych szkoły, a także zróżnicowanych w zgodzie z poziomem kultury literackiej odbiorców (zob. M. Głowiń s ki, Świadectwa i style odbioru. „Teksty” 1975, nr 3).

19 Na temat miejsca utworów Sienkiewicza w międzywojennej szkole zob. Z. B u d r e w i c z, Twórczość Henryka Sienkiewicza z międzywojennych podręczników szkolnych wobec celów wychowania narodowego. W zb.: Henryk Sienkiewicz w szkole, bibliotece i muzeum. Red. T. B uj n i c ki, J. Majc hrzy k. Warszawa 2015.

20 Zob. A. Kło s kow s ka, Szkic zagadnień kultury masowej w Polsce. W: Kultura masowa. Krytyka i obrona. Warszawa 1964. 
bez względu na ich polityczne uwikłania, zgodne były z szerszym nurtem recepcyjnych przemian Trylogii prowadzacych ją ku kulturze popularnej ${ }^{21}$.

Nie oznacza to jednak, że cały ów proces przebiegał bez żadnych przeszkód i oporów. Dowiodły tego już choćby debaty na temat „filmowego” Sienkiewicza, które miały w roku 1966 swoją część niejawną, jaką były spotkania rozmaitych gremiów filmowych podejmujących decyzje produkcyjne (można je odtworzyć na podstawie stenogramów zachowanych w Archiwum Filmoteki Narodowej i w Archiwum Akt Nowych), oraz publiczną, udokumentowaną zapiskami prasowymi, z udziałem zarówno filmowców i publicystów, jak i zwykłych widzów. Wiele szczegółowych informacji na temat kulisów powstawania sienkiewiczowskich ekranizacji zawiera praca Piotra Kurpiewskiego Historia na ekranie Polski Ludowej. Jeden ze zrelacjonowanych w niej sporów dotyczy dokonanej w kwietniu 1966 oceny scenariusza Pana Wołodyjowskiego. Organem powołanym do tego rodzaju weryfikacji była Komisja Ocen Scenariuszy, instancja, która pełniąc prewencyjne funkcje cenzorskie (zasiadali w niej również pracownicy GUKPPiW), dbała o właściwy ideowy wydźwięk produkcji filmowych ${ }^{22}$. Z cytowanych przez Kurpiewskiego wypowiedzi jasno wynika, iż mimo rocznicowej okazji pomysł zekranizowania powieści nie miał wśród filmowych decydentów jednoznacznego poparcia. Sens adaptacji kwestionował Krzysztof Teodor Toeplitz, argumentujący, że - w odróżnieniu od Krzyżaków - ostatnia część Trylogii nie ma żadnych walorów politycznych. Poważniejsze, ideologiczne zarzuty formułował kolejny członek komisji Jan Gerhard. W jego ujęciu bohaterami utworu mieli być „rozmodleni, łzawo-religijnie rozbabrani, tępi, ciemni rębacze”, postać tytułowa została zaś określona jako „figura z rekwizytorni [prymasa] Wyszyńskiego" 23 . Gerhard zakwestionował także jakąkolwiek możliwość zaadaptowania Sienkiewiczowskiego przesłania do współczesnej sytuacji politycznej:

Sądzę, że czas już, aby dojść do tego rozeznania, że sienkiewiczowski patriotyzm nie tylko nie ma nic wspólnego z naszym, mam na myśli patriotyzm Trylogii, lecz wręcz przeciwnie, znajduje się na egzaltowanych, mistycznych i mrocznych pozycjach aktualnego przeciwnika klasowego i politycznego ${ }^{24}$.

Owe negatywne głosy nie wstrzymywały wszakże akceptacji scenariusza filmu przez komisję. Należy więc założyć, że ważniejsza niż poglądy pojedynczych jej członków była w tym momencie zgoda centralnych czynników partyjnych na tę ekranizację ${ }^{25}$. O istnieniu takiej woli politycznej może również świadczyć opublikowany trzy miesiące później w warszawskiej „Kulturze” zapis redakcyjnej debaty dotyczącej filmowania Trylogii, w której wzięli udział Krzysztof Teodor Toeplitz,

W tym miejscu jedynie sygnalizuję szerszy problem wpływu przemian kulturowych na recepcję cyklu, skupiając w artykule uwagę na politycznym wymiarze jego jubileuszowej lektury.

Zob. E. Zaji č e k, Poza ekranem. Kinematografia polska 1896-2005. Wyd. 2, uzup. i rozszerz. Warszawa 2009, s. 223. Na temat politycznych mechanizmów oceny polskich produkcji filmowych w latach sześćdziesiątych pisała również A. M i s i a k w pracy Kinematograf kontrolowany. Cenzura filmowa $w$ kraju socjalistycznym i demokratycznym (PRL i USA). Analiza socjologiczna (Kraków 2006, s. 169-208).

Cyt. za: P. Ku r pi ew s k i, Historia na ekranie Polski Ludowej. Gdańsk 2017, s. 130-131.

Ibidem, s. 131.

Jednym z powodów owej odgórnej akceptacji mogła być nadzieja na powtórzenie finansowego sukcesu Krzyżaków (zob. Zaji č e k, op. cit., s. 201-202). 
Aleksander Ford, Zbigniew Klaczyński, Jerzy S. Stawiński, Stanisław Trepczyński oraz, na prawach późniejszych dopowiedzeń do stenogramu, Bohdan Czeszko i Julian Krzyżanowski ${ }^{26}$. Co bowiem znamienne, prowadzący rozmowę Toeplitz, mimo że oskarża cykl o anachroniczność, religianctwo, „płycizny i schematy sytuacyjne, psychologiczne, fabularne" 27 , nie wraca do wcześniejszych obiekcji dotyczacych samego sensu adaptacji. Wbrew tytułowi debaty uwaga dyskutantów bardziej niż na pytaniu: „czy ekranizować”, skupia się na tym, jak to robić. Warto też podkreślić fakt, iż w publicystycznych wypowiedziach oprócz Pana Wołodyjowskiego i Potopu, nad którymi prace scenariuszowe już trwały, pojawia się również - pomijane przez filmowców z przyczyn politycznych - Ogniem i mieczem. Dyskusja w „Kulturze” toczy się głównie wokół - możliwych do wykorzystania w ekranizacjach - konwencji oraz wyzwań związanych z historyczno-ideologicznym zabarwieniem powieści, zapisanych przez Toeplitza w formie następujących pytań:

czy Sienkiewicza wolno uwspółcześniać, a jeśli tak, to jak? [...] Czy mamy starać się o dopracowanie prawdy historycznej tamtych czasów, rewidując Sienkiewicza - czy raczej przeciwnie: iść jego śladem, nie wdając się w poprawki historyczne ${ }^{28}$.

Głównym tematem debaty stał się więc problem zakresu przekształceń poszczególnych części Trylogii: jako fabuł historycznych (wtedy za kluczowe należy uznać pytanie o ewentualne poprawki dotyczace oceny XVII w.) lub też jako opowieści przygodowych, gdzie przeszłość stanowi jedynie barwne tło. Spośród zwolenników pierwszej opcji obrońca integralności ideowo-historycznego przekazu był Stawiński, podkreślający, że „W ramach [...] epoki nie możemy zmieniać praw, które środowiskiem rządziły" ${ }^{29}$. Jeśli natomiast chodzi o propozycje stworzenia filmów przygodowych, to historyczność była w nich utożsamiana $z$ wymiarem heroiczno-legendowym, a nie rekonstrukcyjnym (Trepczyński, Kleczkowski). Najbardziej radykalny $\mathrm{w}$ chęci odhistorycznienia sienkiewiczowskich adaptacji był Czeszko, szukający analogii dla powieści noblisty w wydanym w Polsce kilka lat wcześniej Władcy pierścieni, cyklu klechd - jak określił utwór J. R. R. Tolkiena - również pisanego „dla pokrzepienia serc watpiących w to, że męstwo i wierność, poświęcenie i dzielność mają rację bytu [...] i że obrona własnej ziemi przed zakusami wrogich sił jest godna ofiary najwyższej” ${ }^{30}$. Co więcej, dostrzegając podobieństwo fantastycznych postaci angielskiego autora do bohaterów Sienkiewicza (np. hobbita Bilba do Zagłoby), Czeszko sugerował przesunięcie polskich ekranizacji ku podobnej jak w powieści Tolkiena „realistycznej baśniowości” z rozbudowanym, wiarygodnym obyczajowym tłem przygodowym, natomiast bez ambicji rekonstrukcyjnych w stosunku do wielkiej historii.

Przemyśleniami nad filmową wersją Potopu podzielił się w dyskusji Ford, uważany w tym czasie za jedynego możliwego realizatora tej ekranizacji. Proponował on stworzenie „filmu historycznego z wszelkimi walorami filmu przygodowego”, 
skorygowanego wszakże „w imię historycznej prawdy”31. Wyraźnie świadczy to o chęci pogodzenia stronników wierności wobec powieści z tymi, dla których warunkiem zgody na ekranizację było dostosowanie scenariusza do politycznych wymogów współczesności, czemu w drugiej części Trylogii najbardziej miała zagrażać katolicka tożsamość bohaterów. Stąd np. argument o możliwości zachowania Sienkiewiczowskiego „religianctwa” tylko w takim stopniu, w jakim zostanie ono odczytane „w zwiazku z wiekiem, w którym się to działo”, stąd też strach przed nadmiernie rozbudowaną sekwencją obrony Częstochowy, która miała być w filmie sprowadzona „do właściwych rozmiarów”32. Podobne w gruncie rzeczy stanowisko w tej kwestii deklarował również Krzyżanowski piszący: „Częstochowy pomijać nie można, ale jak słusznie wskazano w dyskusji, należy jej wyznaczyć miejsce dość skromne”33. Szerzej zaś wypowiedział się on o „pierwiastkach religijnych” cyklu, twierdząc, że zaliczają się one, co prawda, do polskiej kultury barokowej, lecz „nie należy w jej eksponowaniu przesadzać", przywoływał tu jednak argumenty nie tyle ideologiczne, ile literackie:

O życiu religijnym Wołodyjowskiego Sienkiewicz nic nie mówi, a Zagłoba w chwili, gdy grozi mu niechybna śmierć, nie do „Królowej anielskiej” się modli, lecz mówi „zginę ja i pchły moje”- no i nie ginie. Słowem, pisarz raczej skąpo akcentował na kartach Trylogii zjawiska życia religijnego ${ }^{34}$.

Zważmy wszakże w kontekście ostatniego zdania, jak wybiórczo zostały dobrane zaprezentowane przykłady, skoro zabrakło zarówno Podbipięty zwracającego się przecież w chwili ostatecznej właśnie do „Królowej Anielskiej”, jak i Kmicica, którego religijności też trudno byłoby zaprzeczyć. Wypowiedź tę należałoby więc raczej uznać za kamuflowanie religijnej problematyki cyklu przez uczonego, być może motywowane chęcią obrony pisarza przed komunistycznymi ideologami.

Wynikiem zaproszenia przez Toeplitza do dyskusji nad „filmowym” Sienkiewiczem także czytelników pisma stała się kolejna publikacja w „Kulturze”35. Należy podkreślić większe niż w poprzedniej debacie zróżnicowanie ocen. Mamy tu podejście apologetyczne (,Sienkiewicz jest tak doskonałym klasykiem, że jego dzieła nie wymagają najmniejszych poprawek" ${ }^{36}$ ), ale i negowanie sensu przenoszenia fabuł pisarza na ekran i to motywowane zarówno względami artystycznymi, jak i politycznymi. Pojawia się więc lista ekranizacyjnych zagrożeń: „Rzecz tkwi w zubożeniu akcji, w naruszonej chronologii poszczególnych jej wątków, w skrótach, w lukach, w przeinaczeniach i uproszczeniach [...]"37. Zostaje też postawione pytanie:

Czy [...] warto prowadzić akademickie dyskusje, a następnie ponosić nie tylko finansowe koszty filmowania różnych dzieł klasyki literackiej, aby znów przeżywać niedosyt i rozczarowanie, nieproporcjonalne do wysiłku reżysera, aktorów i wielu specjalistów zatrudnionych w produkcji filmowej? ${ }^{38}$

Ibidem, s. 6.

Ibidem.

Ibidem, s. 7.

Ibidem.

Czy i jak ekranizować Sienkiewicza. Listy od czytelników. Jw., nr 32.

Ibidem, s. 3.

Ibidem.

Ibidem. 
Natomiast w odniesieniu do ideologii dzieła możemy przeczytać:

W Trylogii nie ma już nic żywego, co by mogło „pokrzepić dzisiejsze serca”. Był czas, gdy naród był tak chory, że trzeba mu było zmyśleń, aby nie upadł na duchu. Dziś byłoby to niebezpieczne ${ }^{39}$.

Inna zaś wypowiedź dotyczy szkód, jakie Sienkiewicz poczynił w międzywojennej szkole:

lektura Ogniem i mieczem, opracowywana w ciagu całego półrocza wychowywała młodzież pochodzenia mieszczańsko-inteligenckiego w duchu niechęci do mas ludowych i ciasnego szowinizmu ${ }^{40}$.

Przywołane głosy ujawniaja główne obawy i nadzieje wiązane z filmowaniem historycznego cyklu. Jasne wydają się zarówno mechanizmy obrony pisarza, jak i ataku na niego. Jeśli więc zwolennicy Sienkiewicza starali się zneutralizować zarzuty ideologiczne, eksponując legendowy wymiar obrazu przeszłości czy też skupiając uwage na walorach artystycznych, to przeciwnicy sięgali do repertuaru argumentów politycznych, czytając Trylogię zgodnie z wytycznymi marksizmu.

Kolejny kontekst sienkiewiczowskiej dyskusji łączy się $\mathrm{z}$ obradami gremium debatujacego w roku 1966 nad „syntezą dorobku kultury polskiej w tysiącletniej historii państwa, naszym wkładem w rozwój światowej kultury, ze szczególnym uwzględnieniem dwudziestolecia Polski Ludowej" ${ }^{11}$. Chodzi tu o Kongres Kultury Polskiej zwołany z okazji Obchodów Tysiąclecia Państwa Polskiego w celu podkreślenia pieczy, jaką Polska Ludowa objęła nad kulturowym dziedzictwem, a także dla uwypuklenia jej roli mecenasa w odniesieniu do współczesnej aktywności twórczej. Oczywiście, problem pisarstwa Sienkiewicza był tam tematem marginalnym. Pamiętajmy jednak, iż w tego typu politycznych przedsięwzięciach liczyły się zarówno treści wypowiedziane, jak i przemilczane. Znaczące wydaje się zatem pominięcie nazwiska autora Ogniem i mieczem przez przewodniczącego Komitetu do Spraw Radia i Telewizji Włodzimierza Sokorskiego na liście wyliczonych przez niego twórców, których dzieła „o wysokiej randze artystycznej” zostały wydane po wojnie w masowych nakładach ${ }^{42}$. Znamienne jest też, że w przemówieniu prominentnego członka partii - Zenona Kliszki, podstawowym kryterium „krytycznej oceny i świadomego wyboru tradycji” nadal była jej postępowość. Eksponował on więc głównie to, co „do skarbnicy kultury narodowej wniosły warstwy ludowe: chłop, plebs miejski, a później klasa robotnicza" 43 .

Na tle ortodoksyjnych wystạpień polityków większą ideową otwartością charakteryzowały się wypowiedzi twórców kultury wyraźnie wskazujących na potrzebę poszerzenia i przedefiniowania historyczno-kulturowych źródeł współczesności tak, by nie zamykać się - cytuję za jedną z wypowiedzi - „w kręgach zdobytych

S. W. Balic ki, wstęp w zb.: Kongres Kultury Polskiej, 7-9 października 1966. Materiały i dokumenty. Red. ... Warszawa 1967, s. 5. Sienkiewicza wśród następujących polskich autorów: A. Mickiewicza, B. Prusa, J. I. Kraszewskiego, M. Konopnickiej i S. Żeromskiego.

43 
osiagnnięć i zdobytej wiedzy” i nie kreować ,jakichś zamrożonych dóbr”44. Również $\mathrm{w}$ postulowanym $\mathrm{w}$ innym wystapieniu łączeniu przeszłości $\mathrm{z}$ teraźniejszością można odczytać coś więcej niż tylko dbałość o ideologiczną użyteczność historycznych narracji. Chodziło tam także o zrozumienie ich emocjonalnej więzi ze współczesnością ${ }^{45}$.

Zadania przeformułowania wymowy Trylogii w taki sposób, by zmieściła się ona w ramach zaakceptowanej „tradycji socjalistycznego państwa”, podjął się na kongresie Jarosław Iwaszkiewicz. Mówca, rozbrajając ideologiczne zagrożenia stwarzane przez to dzieło, jednocześnie podkreślał anachroniczność jego obrazu przeszłości, jak i ważność cyklu w kontekście kulturowej pamięci: „Szlachecczyzna [!] Sienkiewicza częściowo się zdezaktualizowała i przestała być groźna, częściowo zaś weszła w nasz krwioobieg narodowy [...]" ${ }^{46}$. W tym drugim przypadku jej wartość wiazzał autor Sławy i chwały z egalitaryzmem najwyższej próby, z wytwarzaną dzięki lekturze polską, wspólnotową tożsamością przejawiająca się choćby w „sienkiewiczowskich pseudonimach, które mnożyły się wśród partyzantów AK i AL”47. Istotne stało się także wyeksponowanie uniwersalności literackiego przekazu. Wsparł się tu Iwaszkiewicz odwołaniem do noblowskiej mowy Williama Faulknera, podkreślając za amerykańskim pisarzem wartość cyklu jako „ponadczasowej powieści o rzeczach, które nie starzeją się i które pasjonują wszystkie pokolenia, o miłości, o patriotyzmie, o walce w imię lepszego jutra, o ciężkich zadaniach, jakie się podejmuje "dla pokrzepienia serc" "48. Nie jest to więc jedynie łagodzenie tonu, ale bardziej radykalna próba przewartościowania ideowej oceny dzieła i przesunięcia jego odbioru na tory artyzmu i wartości uniwersalnych.

Za ostatni przywołany nurt wypowiedzi o nobliście niech posłuży rocznicowa dysputa naukowa przeprowadzona w ramach poświęconej twórcy, zorganizowanej w listopadzie 1966 w Instytucie Badań Literackich, międzynarodowej konferencji, zwieńczona po dwu latach publikacją zbioru artykułów ${ }^{49}$. Jako główny cel obrad należałoby wskazać poszukiwanie dla tej twórczości nowego miejsca na mapie literatury polskiej, nie wyznaczanego już ani stopniem postępowości pisarza, ani siłą uczuć patriotycznych, lecz literackimi wartościami jego dzieł. Jeśli więc spojrzymy na dorobek konferencji, to na czoło wysuwają się dwie kwestie: odbioru twórczości autora Trylogii w Polsce i na świecie oraz problemy artyzmu. W programowym artykule otwierającym wydane drukiem materiały Wyka następująco powiązał zagadnienia recepcyjne i warsztatowe:

J. Iw a s z ki ew i c z, Kultura świadectwem trwałości. W zb.: jw., s. 65-66.

Zob. K. Wy ka, O żywym kontakcie z dziedzictwem kultury. W zb.: jw., s. 126-127.

Iw a s zkiewicz, op. cit., s. 68 .

Ibidem.

Ibidem.

Henryk Sienkiewicz. Twórczość i recepcja światowa. Materiały konferencji naukowej, listopad 1966. Red. A. Pi or un ow a, K. Wy ka. Kraków 1968. Ze względu na fakt, że pokonferencyjne wydawnictwo poszerzyło liczbę artykułów w stosunku do liczby wygłoszonych referatów o 5 tekstów będących przedrukami z czasopism, pomocą w oddzieleniu zasobu wystąpień konferencyjnych od wydrukowanych prac stało się sprawozdanie z obrad (K. Tokarzów na, T. Tys zki ewi c zówn a, Henryk Sienkiewicz - twórczość i recepcja światowa. Sesja naukowa Instytutu Badań Literackich PAN. 〈Warszawa, 17-19 listopada 1966〉. „Pamiętnik Literacki” 1967, z. 3). 
recepcja ta chyba coraz wyraźniej opiera się na walorach artystycznych jego [tj. Sienkiewicza] dzieł, w określonym stopniu na walorach wychowawczych, a w najmniejszym zapewne stopniu - na ideologii samego pisarza oraz ideologii jego tworów pisanych ${ }^{50}$.

Samą konferencję zdominowały informacje na temat popularności autora Trylogii poza naszym krajem, mierzone zainteresowaniem tłumaczy i literaturoznawców, liczbą translacji, ich nakładami. Na 18 wystapień 10 dotyczyło odbioru Sienkiewicza za granica (w tym oczywiście w Rosji i w ZSRR), jedno stanowiło opis różnic między jego polskim i światowym postrzeganiem, następne dotyczyło filmowych adaptacji, kolejne zaś przybliżało recepcję beletrystyki Sienkiewicza przez historyków. Również u podstaw drugiego $\mathrm{z}$ tematycznych nurtów obrad stały próby wykorzystania takich narzędzi opisu dzieł noblisty, które pozwoliłyby zrozumieć fenomen jego czytelniczej kariery. Autorzy referatów uciekając od ideologii, skupiali uwagę na stylistyce utworów, badali ich rys genologiczny szczególnie w kontekście związków z gatunkami kultury popularnej, z ludową epiką i baśnią, a także odsłaniali pierwiastki antyczne i folklorystyczne ${ }^{51}$.

Polskość XVII-wiecznego cyklu zyskiwała w tych wystapieniach wymiar ogólnoludzki, co podkreślał Wyka w cytowanym właśnie artykule:

W każdym [...] przekazie pisarstwo Sienkiewicza oddziaływa w myśl odwiecznych tęsknot do człowieka, który zdolny jest stawić czoła przygodzie i światu. Oraz tęsknot za przygodą, która rzeczywistość czyni bardziej urozmaiconą i bogatszą ${ }^{52}$.

To właśnie podniesienie tego egzystencjalnego charakteru twórczości polskiego pisarza miało wyzwolić lekturę jego dzieł z wcześniejszych - jak je postrzegał badacz - ograniczeń ideowo-politycznych.

Na tle większości wypowiedzi konferencyjnych uwage zwraca odmienny wydźwięk jednego z referatów (Janiny Kulczyckiej-Saloni), który - w wersji powielonej przed konferencją i przeznaczonej do użytku prelegentów - dotyczył stanu badań sienkiewiczowskich oraz zagadnień edytorskich i czytelniczych związanych $z$ tą twórczością. W wersji wygłoszonej i oddanej do druku przyjął on natomiast formę studium porównawczego dwu koncepcji sztuki pisarskiej i dwu światopoglądów: Sienkiewicza oraz Prusa ${ }^{53}$. Jedyna to wypowiedź nie tylko mocno wchodząca w problematykę ideowej postawy noblisty, ale - przez jej skontrastowanie z założeniami drugiego $\mathrm{z}$ twórców - ujawniająca krytyczną ocenę spuścizny literackiej autora Trylogii, o czym dowiadujemy się z pokonferencyjnej relacji:

Śledząc wydźwięk dotychczasowych wypowiedzi, z których można było odnieść wrażenie, że toczy się coś na kształt procesu kanonizacyjnego, referentka [tj. Kulczycka-Saloni] postanowiła przyjąć niepopularną rolę prokuratora ${ }^{54}$.

K. Wy k a, O sztuce pisarskiej Sienkiewicza. W zb.: Henryk Sienkiewicz, s. 10.

Dopowiedzmy jeszcze, że w publikacji książkowej aż 15 rozpraw dotyczy szeroko rozumianej recepcji (tłumaczenia, prace krytyczne, ekranizacje, przetworzenia komiksowe i w formie przeróbek młodzieżowo-ludowych), 8 zaś odnosi się do rozmaitych problemów warsztatowych.

Wy k a, O sztuce pisarskiej Sienkiewicza, s. 45.

Wersja powielaczowa została zatytułowana Sienkiewicz $w$ Polsce Ludowej, wygłoszony referat nosił tytuł Sienkiewicz $i$ Prus i był najprawdopodobniej tożsamy z opublikowanym w tym samym czasie artykułem badaczki (J. Kulczy cka-Saloni, Sienkiewicz i Prus. „Pamiętnik Literacki” 1966, z. 3), którego przedruk znalazł się w książce pokonferencyjnej.

Tokarzówna, Tyszkiewiczówna, op. cit., s. 279. 
W dalszej zaś części sprawozdania dotyczącego tego referatu czytamy:

Patriotyzm Sienkiewicza, polegający na gloryfikowaniu przeszłości, autorka porównała z pełnym odpowiedzialności i troski patriotyzmem Prusa, myślącego o aktualnych potrzebach narodu i zagrożeniach współczesnego pokolenia, a w doświadczeniach przeszłości szukającego ostrzeżeń ${ }^{55}$.

Co znamienne jednak dla jubileuszowej atmosfery panującej na naukowym zjeździe, w dyskusji nad tym wystąpieniem zarysował się wyraźny front obrony bohatera konferencji, skupiony głównie wokół przedstawienia w pozytywnym świetle oddziaływania na czytelników oraz wokół prób odnalezienia uzasadnień dla jego postawy „w dyspozycjach właściwych mentalności polskiej” ${ }^{56}$. Należy tu wszakże podkreślić, że usprawiedliwianie wymowy prozy Sienkiewicza przez eksponowanie jej narodowej specyfiki nie przystaje do przesłania większości referatów wpisujących się w szerszy program przekształcania autora Trylogii z ideologa polskości w artystę o wymiarze międzynarodowym. Pokonferencyjne sprawozdanie nasuwa zresztą ogólniejszą myśl o tym, że część dyskusyjna nie dała się podporządkować w takim stopniu, jak referaty jednolitej linii ideowej, znacznie wyraźniej ujawniając emocjonalny i aktualizujący wymiar lektury dzieł Sienkiewicza. W obronę wzięła ten sposób ich odbioru wnuczka noblisty - Maria Korniłowicz, która zaprzeczyła tezie, że pisarstwo to „pełni obecnie już tylko funkcję beletrystyczno-rozrywkowa” 57 . Natomiast na negatywny wymiar współczesnego „patriotyzmu emocjonalnego” pozostającego pod wpływem oddziaływania wzorców Sienkiewiczowskich zwrócił uwagę Adam Kersten $^{58}$.

Uogólniając obserwacje dotyczące jubileuszowego „oswajania” pisarza w roku 1966, należy podkreślić, że w publicystycznych i naukowych wypowiedziach z tego okresu na dalszy plan schodzi nie tylko twórczość współczesna, ale i powieść Krzyżacy. Było to skutkiem, po pierwsze, pojawienia się bardziej efektywnego niż książka narzędzia propagandowego, jakim był film Forda, po drugie zaś, dominujacego przekonania, że to jednak Trylogia stanowi opus magnum Sienkiewicza. Propagowany w tym czasie tryb jej lektury, odwołujący się głównie do wartości artystycznych i rozrywkowych, zyskał też - niezależnie od swoich powiązań z przekształceniami społecznymi i rosnącymi wpływami kultury masowej - wymiar polityczny. Tak więc, odpowiadając na pytanie o miejsce Sienkiewiczowskiej XVII-wiecznej wizji przeszłości w ramach poszerzanej w latach sześćdziesiątych tradycji historycznej, można przyjąć, iż ceną akceptacji było, paradoksalnie, odhistorycznienie tego obrazu dokonujące się m.in. przez neutralizowanie najpełniej wyrazistych skojarzeń wiążących literackich bohaterów $\mathrm{z}$ formacją kulturową sarmatyzmu, a także przez wyciszanie kontrowersji odnoszących się do pisarza jako

Ibidem. Krytyczne przeciwstawienie „wstecznego” Sienkiewicza „postępowemu” Prusowi pojawia się u J. Kulc zy cki ej-Sal on i (Sienkiewicz i Prus. W zb.: Sienkiewicz, s. 217) również w opublikowanym artykule i dotyczy m.in. odmienności zadań przypisywanych przez obu twórców literaturze: „Mamy [...] wyraźne sformułowanie dwóch postaw: Prusowskiej, zrodzonej z przemyślenia i przyswojenia tego, co było zdobyczą nowszej myśli europejskiej, i Sienkiewiczowskiej, związanej ze sprymitywizowanym, uproszczonym dziedzictwem romantyzmu".

Ibidem.

Ibidem, s. 280. 
twórcy narodowych mitów. Dość powiedzieć, że nawet we wzmiankowanej wcześniej księdze pokonferencyjnej, którą wypada postrzegać jako zapis najbardziej żywych w tym czasie nurtów refleksji nad noblistą, Stanisław Brzozowski jako krytyk autora Trylogii pojawia się zaledwie kilkakrotnie w krótkich, najczęściej jednozdaniowych omówieniach głównie w celu zakwestionowania owych opinii, przy występującym zaś dwa razy na kartach pracy nazwisku Gombrowicza zabrakło jakichkolwiek antysienkiewiczowskich odniesien.

Potwierdzeniem tych recepcyjnych tendencji jest również kinowa ekranizacja Pana Wołodyjowskiego z roku 1969, wyraźnie filtrująca cechy szlacheckości przez pryzmat chwytów komicznych związanych $\mathrm{z}$ wizerunkiem Zagłoby. Podporządkowanie przez Jerzego Hoffmana historyczności filmu bezpiecznemu politycznie nurtowi przygody pozwala przyznać rację tym recenzentom, którzy nad ideowy wymiar adaptacji przedkładali jej walory ludyczne ${ }^{59}$. Jeszcze bardziej jest to widoczne w nakręconym przez Pawła Komorowskiego - z myślą o młodzieżowym adresacie - serialu Przygody pana Michała (1968), składającym się z 13 dwudziestokilkuminutowych odcinków konstruowanych wokół kolejnych wyzwań stawianych przed bohaterami. Pisano nawet w kontekście obu fabuł: kinowej i telewizyjnej, o ich komiksowości. Nie miało to być wszakże określenie deprecjonujące. Chodziło raczej o doprecyzowanie sposobu łączenia przygód $z$ historycznym tłem. Jak bowiem podkreślał autor jednej $z$ recenzji: „Ladny i udany film Hoffmana jest komiksem z samego założenia"60. Komiksowość jako konwencja przedstawienia przesunęła - według krytyka - akcent $z$ problematyzowania historii na jej oswajanie i odmalowywanie „w ciagu ilustracji” oraz obrazowanie powieściowych konfliktów „w umownej, przygodowej konwencji”, co Hoffman zrealizował w sposób ,jednolity, klarowny, strawny" 61.

W opozycji do zaprezentowanego „oficjalnego” nurtu odbioru Trylogii odrywającego jej lekturę od polskiego „tu i teraz” można postawić te okołorocznicowe wypowiedzi, w których autorzy wykorzystali noblistę do podjęcia drażliwych problemów współczesności. Za dwie najważniejsze uznaje esej Jacka Łukasiewicza z roku 1965 Zagtoba $w$ piekle, osnuty wokół postaci będącej jednym z symboli polskiego anachronizmu i zaściankowości, oraz opublikowany rok później szkic Andrzeja Kijowskiego Sienkiewicz i polska nerwica, diagnozujący wpływ noblisty na duchowość narodową. Są to teksty nie tylko wyróżniające się na tle opisanego wcześniej sposobu recepcji wyciszającego ideowe kontrowersje, ale również opozycyjne względem siebie. O ile bowiem Łukasiewicz aktualizował pozytywny wymiar Sienkiewiczowskiego przekazu, mianując Zagłobę - pragmatycznego, doceniającego konieczność codziennych kompromisów z polityka - patronem współczesnych Polaków zmuszonych w PRL do „życia na niby”, o tyle Kijowski w specyficzny spo-

Zob. J. Fuksiewicz, „Pan Wołodyjowski”, czyli triumf dobrej roboty. „Kultura” 1969, nr 14. - A. Jackiewicz, Piękny komiks o matym rycerzu. „Życie Literackie” 1969, nr 14. - R. Marszałek, W sprawie szabli. „Współczesność” 1969, nr 9.

61 Ibidem. Zob. też szersze rozważania o komiksowości wielkich historycznych produkcji filmowych: R. Mar s załe k, Filmowa pop-historia. Kraków 1984, s. 143-154. 
sób wykorzystał podstawową dla marksistowskich ocen antynomię wstecznictwa i postępowości. Przewrotna pochwała prostoty fabularnej i jednoznaczności aksjologicznej dzieł noblisty została podszyta w szkicu Kijowskiego krytyczną refleksją na temat familiarnej mitologizacji historycznych światów, stanowiącą ostrzeżenie przed niebezpieczeństwem wynikającym ze zbytniego zawierzenia moralistycznej prostocie „baśni na tle dziejowym”. Mimo iż autor Arcydzieła nieznanego pozornie kwestionował - podobnie jak przywoływani wcześniej Iwaszkiewicz i Wyka - sens całego peerelowskiego sporu o autora Krzyżaków, pisząc: „Walka z Sienkiewiczem jako ideologiem byłaby dziś równie anachroniczna, jak anachroniczne byłoby uznanie go za ideologa” 62 , nie odmawiał mu wszakże „rządu dusz” nad Polakami. Ów wpływ miałby się jednak realizować nie w doraźnej aktualizacji poglądów twórcy, jak obawiali się jego marksistowscy krytycy, lecz bardziej w związku z zagrożeniami opisywanymi już wcześniej przez Brzozowskiego i Gombrowicza, a więc w popularności opowieści drążących archetypiczne pokłady polskiego życia duchowego, w atrakcyjności fabuł, które uwodzą czytelników fantazmatem skutecznego powrotu do dawnej wielkości i sielskiej bezgrzeszności:

U Sienkiewicza [...] powrót jest zupełny i szczęście całkowite, albowiem rzeczywistość jego powieści poddana jest tym samym prawom baśniowym co fabuła. Nie tylko Skrzetuski i Kmicic będą do śmierci szczęśliwi ze swoimi królewnami odnalezionymi; Polska, jak oni, będzie na wieki szczęśliwa i zwycięska, gdyż raz na zawsze pobiła hajdamaków i wygnała Szwedów ${ }^{63}$.

Jak się też okazało kilka lat później, to Kijowski w swej diagnozie pocieszycielskiego przesłania Trylogii lepiej rozpoznał kompensacyjne potrzeby Polaków niż ci publicyści i uczeni, którzy - w myśl politycznego zapotrzebowania - eksponowali głównie artystyczne i ogólnoludzkie walory cyklu, ignorując wpisane weń narodowe mity. Za sprawa bowiem wyreżyserowanego przez Hoffmana Potopu ${ }^{64}$ ideowy wymiar krzepienia serc Sienkiewiczem potwierdził swą aktualność w kolejnej politycznej dekadzie PRL. Ujawniła to kilkuletnia publicystyczna debata nad filmem, w którym Polacy z epoki wczesnego Gierka odnaleźli możliwą do zaakceptowania wersję dziejów - zarazem atrakcyjną fabularnie, jak i kojącą narodowe kompleksy ${ }^{65}$. W porównaniu z Panem Wołodyjowskim, poszerzającym wymiar przygodowy kosztem historyczno-ideologicznego, w kolejnej adaptacji mamy do czynienia z równoważeniem obu rysów opowieści przy dodatkowym wyostrzeniu polityczno-obyczajowych skrajności (zdrada, warcholstwo, okrucieństwo przeciwstawione patriotyzmowi, poświęceniu, przebaczeniu), a także ze skuteczną próbą podporządkowania fabuły hasłu odkupienia win i polsko-polskiego pojednania. Sienkie-

A. Kijowski, Sienkiewicz i polska nerwica. W: Granice literatury. Wybór szkiców krytycznych i historycznych. T. 1. Wybór, oprac., wstęp T. B u rek. Warszawa 1991, s. 238 (pierwodruk: „Tygodnik Powszechny" 1966, nr 46). Ibidem.

64 Po wymuszonej na A. Fordzie emigracji z Polski ekranizacją drugiej części Trylogii zajął się Hoffman. On też był współautorem (razem z W. Żukrowskim i A. Kerstenem) zatwierdzonego do realizacji w roku 1969 scenariusza filmu. W kinach Potop pojawił się jesienią 1974.

65 Zob. więcej na temat tej debaty: A. C h o mi u k, Wokót Sienkiewicza. Listy-biografie-ekranizacje. Kraków - Nowy Wiśnicz 2019, s. 150-158. 
wiczowski sarmatyzm przefiltrowany przez medium, które w tym momencie wyraźnie już przejęło od literatury funkcje diagnozowania prawd zbiorowych, stał się więc tradycją dająca zakorzenienie we wspólnocie, choć nie bezgrzesznej, ale przecież zasługującej na uznanie ${ }^{66}$.

Niewątpliwie to dopiero zekranizowany Potop utrafił w czas, w którym pełniejsza akceptacja stworzonego przez Sienkiewicza obrazu przeszłości była już politycznie możliwa ${ }^{67}$. Niewykluczone, że stało się tak za sprawą przydatności przekazu wpisanego w film, związanego $z$ ideowym propagowaniem narodowej jedności i pobudzaniem zbiorowego optymizmu ${ }^{68}$. Sama jednak restytucja mitu o sarmackim dziedzictwie i jego popularyzacja w latach siedemdziesiątych wśród szerokich rzesz Polaków była - w świetle przywołanych tu wypowiedzi - bardziej czymś, co się po prostu zdarzyło, niż przemyślaną strategią władzy ${ }^{69}$. Natomiast skutki tego zjawiska zdają się wykraczać nie tylko poza dekadę gierkowską, ale nawet poza epokę PRL. Albowiem mimo iż Trylogia od paru dziesięcioleci należy do dzieł czytanych głównie $z$ lekturowego obowiązku, to wzmocniony Hoffmanowską ekranizacją Potopu ogólnonarodowy, tożsamościowy wymiar szlacheckiej tradycji okazał się na tyle trwały, że od lat dziewięćdziesiątych otworzył się na kolejne rekonfiguracje idei sarmackiej realizowane zarówno w duchu rozliczeniowym, jak i kompensacyjnym $^{70}$.

Entuzjastyczny odbiór tego historycznego autowizerunku wyrasta z podobnej emocjonalnej potrzeby, co rekordowa popularność zorganizowanej w roku 1979 w krakowskim Muzeum Narodowym wystawy Polaków portret własny. W obu przypadkach wyraźne jest odwołanie do integrującego społeczeństwo poczucia narodowej dumy wyzwalającej się w spotkaniu z wielkością czasów minionych.

67 Symbolicznym świadectwem ideowej zmiany w peerelowskiej polityce historycznej stała się podjęta przez E. Gierka na początku jego rządów, blokowana wcześniej przez W. Gomułkę, decyzja o odbudowie Zamku w Warszawie (zob. Za r e m b a, op. cit., s. 358-361).

68 Jak czytamy w jednym z opracowań, to właśnie rok 1974 można uznać za apogeum Gierkowskiej propagandy sukcesu: „W lipcu wieżę Zamku Królewskiego zwieńczono hełmem, a polscy piłkarze zyskali trzecie miejsce na mistrzostwach świata; we wrześniu odbyła się premiera superprodukcji filmowej Potop w reżyserii Jerzego Hoffmana" (B. B r z o s t e k, PRL: propaganda czy polityka historyczna? W zb.: Polityka czy propaganda. PRL wobec historii. Red. P. Sk i b iń s ki, T. W iś ci cki, M. Wy s o c ki. Warszawa 2009, s. 79).

69 Inaczej wątek odkrywania sarmackiej tożsamości przez obywateli PRL postrzega P. C za plińs ki w pracy Resztki nowoczesności. Dwa studia o literaturze i życiu (Kraków 2011). Nie tylko bowiem przypisuje on obu ekranizacjom Hoffmana istotną rolę sprawczą w konstruowaniu sarmackiej świadomości Polaków, ale i sugeruje, że był to proces w jakimś sensie przez władzę zainspirowany już w epoce gomułkowskiej (jako „konotujący zagubioną wielkość, okazywał się odpowiedzą na kryzys zbiorowej tożsamości i równocześnie korzystnym dla władzy projektem jedności” 〈ibidem, s. 90〉).

70 Na temat miejsca idei sarmackiej w polityczno-kulturowym obiegu po roku 1989 zob. Nowoczesność i sarmatyzm. Red. P. Czapliński. Poznań 2011. „Zwrotowi sarmackiemu” ostatnich dekad został również poświęcony nr 1 „Tekstów Drugich” z roku 2015. O sarmatyzmie rozumianym nieesencjonalnie, a więc nie tyle w znaczeniu formacji kulturowej szlachty polskiej w XVI-XVIII wieku, ile bardziej jako „miejsce wspólne” współczesnych polskich przedstawień tożsamości i świadomości narodowej oraz ciagle aktualny sposób nadawania sensu przeszłości, pisał tam J. Ni e dź wi e dź (Sarmatyzm, czyli tradycja wynaleziona. Jw.). 


\section{Abstract \\ ALEKSANDRA CHOMIUK Maria Curie-Skłodowska University, Lublin ORCID: 0000-0002-3236-615X \\ SIENKIEWICZ'S YEAR 1966 IN THE CONTEXT OF POLISH PEOPLE'S REPUBLIC HISTORICAL POLICY}

The paper refers to the changes in Henryk Sienkiewicz's output reception that took place in the 1960s. The background of the changes is the historical policy of Polish People's Republic shaped at that time by the influence of the communist authorities' argument with the Catholic Church over the ideological dimension of The Millennium of the Polish State celebration. The subject of the analysis contained in this paper are selected debates over Trylogia (The Trilogy) inspired by its writer's $50^{\text {th }}$ death anniversary. Common element of the discussion about Sienkiewicz's image of the $17^{\text {th }}$ century is an attempt to understate the associations connected with national mythology and Sarmatian ideology for the reception that calls for universal values and that sets the work into the context of popular culture. 